\title{
Detecting changes in surface-water area of Lake Kyoga sub-basin using remotely sensed imagery in a changing climate
}

\author{
F.W. N. Nsubuga ${ }^{\mathrm{a}}$, Joel. O. Botai ${ }^{\mathrm{b}}$, Jane. M. Olwoch ${ }^{\mathrm{c}}$, C.J.deW Rautenbach ${ }^{\mathrm{b}}$, Ahmed. M. \\ Kalumba $^{\mathrm{b}}$, Philemon Tsela ${ }^{\mathrm{b}}$, Abiodun. M. Adeola ${ }^{\mathrm{b}}$, Ausi. A. Ssentongo ${ }^{\mathrm{b}}$, Kevin. F. Mearns ${ }^{\mathrm{a}}$. $^{-}$ \\ ${ }^{a}$ UNISA, College of Agric \& Environmental sciences, Department of environmental Science, Florida Campus, \\ Private Bag X6, Florida 170, South Africa. \\ ${ }^{b}$ Department of Geography, Geoinformatics and Meteorology, University of Pretoria, Pretoria, 0002, South \\ Africa. \\ ${ }^{\mathrm{c}}$ South African National Space Agency
}

\begin{abstract}
Detection of changes in Earth surface features, for example lakes, is important for understanding the relationships between human and natural phenomena in order to manage better the increasingly scarce natural resources. This work presents a procedure of using Modified Normalised Difference Water Index (MNDWI) to detect fluctuations of Lake surface-water area and relate it to a changing climate. The study used radiometrically and geometrically rectified Landsat images for 1986, 1995 and 2010 encompassing the Kyoga Basin lakes of Uganda, in order to investigate the changes in surface-water area between the respective years. The Standard Precipitation Index (SPI) and Drought Severity Index (DSI) are applied to show the relationship between variability of surface-water area and climate parameters. The present analysis reveals that surface-water area fluctuation is linked to rainfall variability. In particular, Lake Kyoga sub-basin lakes experienced an increase in surface-water area in 2010 compared to 1986. This work has important implications to water resources management for Lake Kyoga and could be vital to water resource managers across Ugandan lakes.
\end{abstract}

Key words: Climate variability, surface-water area, remote sensing, water resource management, SPI, DSI, Uganda.

\section{Introduction}

Change detection is the process of identifying differences in the state of an object or phenomena by observing it at different times (Singh 1989). It involves the skill of quantifying temporal effects using multi-temporal data sets. The detection of these changes is important in providing information as to what and where the changes have occurred and to analyse these changes in order to manage natural resources better. According to Lu et al. (2004), change detection research provides information on area change and change rate, spatial 
distribution of changed feature types and change trajectories. Change detection has numerous applications which are widely reported in the literature particularly based on the use of remote sensing data and associated techniques, (Schäfer and Lundström 2012; Nath and Deb 2010; Mouchot et al.1991; and Shamsipour et al. 2011) among other examples. The basic principle in using remote sensing data for change detection is that changes in land cover manifests in changes in radiance values. Therefore, the change in radiance could be attributed to land cover change including other factors such as, a) differences in sun angle, b) differences in atmospheric conditions, and c) differences in soil moisture (see Singh 1989 and references there in).

The change detection technique of using remote sensing according to (Schultz 1997) can also be applied in water resources management and monitoring studies, (Abdelsalam et al. 2008; Rasuly et al. 2010; Troitskaya et al.2012; Terekhin, 2013; Niya et al. 2013; Song et al. 2013; Arshad et al. 2014). Monitoring changes in water resources, using Landsat images has become increasingly important in the past years due to uncertainties surrounding climate change effects, development of transport routes, and need for timely information for monitoring and management purposes (Nath and Deb 2010). It is also anticipated that water resources will be hit hard by environmental changes. For example, temperature increase, reduction in precipitation, increased evaporation, and conversion of land cover can alter a basins response to rainfall events resulting in changes in surface-water area (Alcamo et al. 2007). Consequently this impacts on run-off, water volume, variability of river discharges and the seasonal availability of water supply (Alcamo et al. 2007).

Over the past years, significant work has been done on studying water resources especially lakes using satellite images. For example Ouma and Tateishi (2006) studied the East African Great Rift Valley lakes using similar techniques. Whereas Nath and Deb 2010 and Lu et al. 2004 review the various methods used for extracting water information from remote sensing imagery; Xu et al. (2009) on the other hand uses the Normalized Difference Water Index (NDWI) model to extract water bodies of Tangjiashan Barrier Lake from the multi-source satellite images. This approach used in extracting water body information especially in vegetated cover and water mass areas can be applied in similar areas as those found in Uganda in order to monitor the dynamics of surface water during this era of climate change.

The NDWI approach reported first in McFeeters (1996) and later used by Ouma and Tateishi (2006) is derived from Green and Near Infrared Red (NIR) channels spectral signature as given in equation 1 . In these portions of the electromagnetic spectrum, water bodies absorb almost all-incident radiant flux while the land surface reflects significant amounts of nearand mid-infrared energy. The selection of these wavelengths maximises the reflectance properties of water.

$$
\text { NDWI }=\frac{\text { Green }- \text { NIR }}{\text { Green }+ \text { NIR }}
$$

In Equation (1), Green band and NIR bands correspond to band 2 and band 4 respectively of the Landsat TM imagery. The Green band is preferred to the Red band because the Green 
band is relatively insensitive to the background components such as soil (Ji et al. 2009). In equation (1), the presence of water bodies will be denoted by high NDWI values than the other landscapes, because water has a high reflectance in NIR channel and it can restrain the information of forest, farm and grass (McFeeters 1996, Xu 2006, Xu et al. 2009).

The main aim of the current work is to investigate the changes in areal coverage of surfacewater in the Lake Kyoga basin between 1986 and 2010 using Landsat TM and ETM+ imagery. Specifically the objectives of the study are a) to characterise the climatic conditions of Lake Kyoga basin between 1940 and 2009, b) analyse the changes in areal surface-water coverage in Lake Kyoga sub-basin using appropriate water index derived from Landsat imagery of 1986, 1995 and 2010 and c) investigate the linkage between climatic parameters and surface-water area.

This study contributes towards understanding the manifestations of climate variability on communities and could therefore support climate change adaptation and mitigation strategies for the benefit of the vulnerable in communities. Furthermore, extracting water body information from remotely sensed data is an important technique of water resources macroeconomic monitoring, flood disaster monitoring and wetland and shoreline protection. Additionally, accurate extraction of water resources information from remotely sensed images is a significant means for the surveying and dynamic monitoring of water resources (Xu 2006).

\section{Study area}

Lake Kyoga drainage sub-basin is part of the upper Nile river basin system formed by 10 districts ${ }^{1}$. The sub-basin covers an area of $57233 \mathrm{~km}^{2}$, of which open water is $3152 \mathrm{~km}^{2}$ and wetlands are $2356 \mathrm{~km}^{2}$ (UNWDR 2005). At the centre of the sub-basin is a shallow lake (Kyoga), which was formed as a result of up warping in the western and eastern parts of the country many years ago, that led to a reversal of direction of flow of some of the rivers in Uganda (NEMA 2002). Lake Kyoga has a surface area of $2636 \mathrm{~km}^{2}$, with a mean elevation of $1034 \mathrm{~m}$ above mean sea level (amsl). Its maximum depth is $10.7 \mathrm{~m}$; mean depth is $3 \mathrm{~m}$ with a total volume of $7.9 \mathrm{~km}^{3}$ (UNWDR 2005). The catchment of Lake Kyoga is wide as indicated by the Kyoga Water Management Zone (Kwmz) and rainfall stations within are shown in figure 1 .

\footnotetext{
${ }^{1}$ First level administrative regions in Uganda
} 


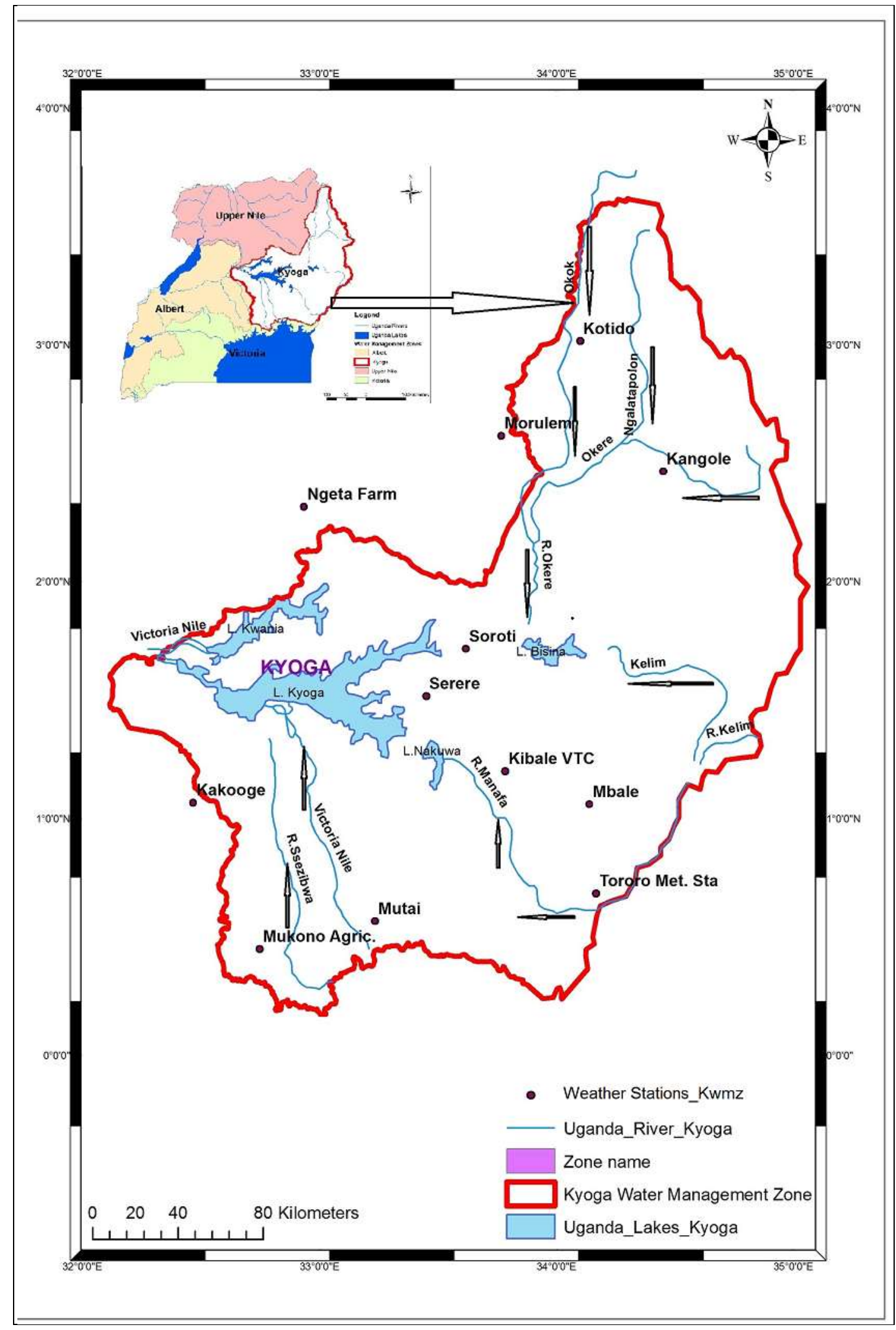

Figure 1. The four water management zones (inset map) and extent of the Kyoga Wmz in Uganda, including weather stations used in the analysis; Rivers partly discharge into wetland areas (not shown) before they join the main lakes; arrows indicate direction of flow. 
The climate experienced within Kyoga Wmz is the modified equatorial type of climate. Maximum temperatures are high during the months of December, January, February, and March. During this period, minimum temperatures are in the range of $15^{\circ} \mathrm{C}$ and $17^{\circ} \mathrm{C}$. Mean historical monthly rainfall records from selected stations for the water management zone reveal a spread out rainfall distribution (Figure 2). Areas to the north receive about $600 \mathrm{~mm}$ of annual precipitation in a single rain season, while the south and south western part of the zone receive rainfall of up to $1500 \mathrm{~mm}$ over two rain peaks (COWI 2010). Mean monthly temperature and rainfall characteristics for the zone are displayed in (Figure 2), which is derived by averaging area records of the meteorological stations with in the Kwmz.

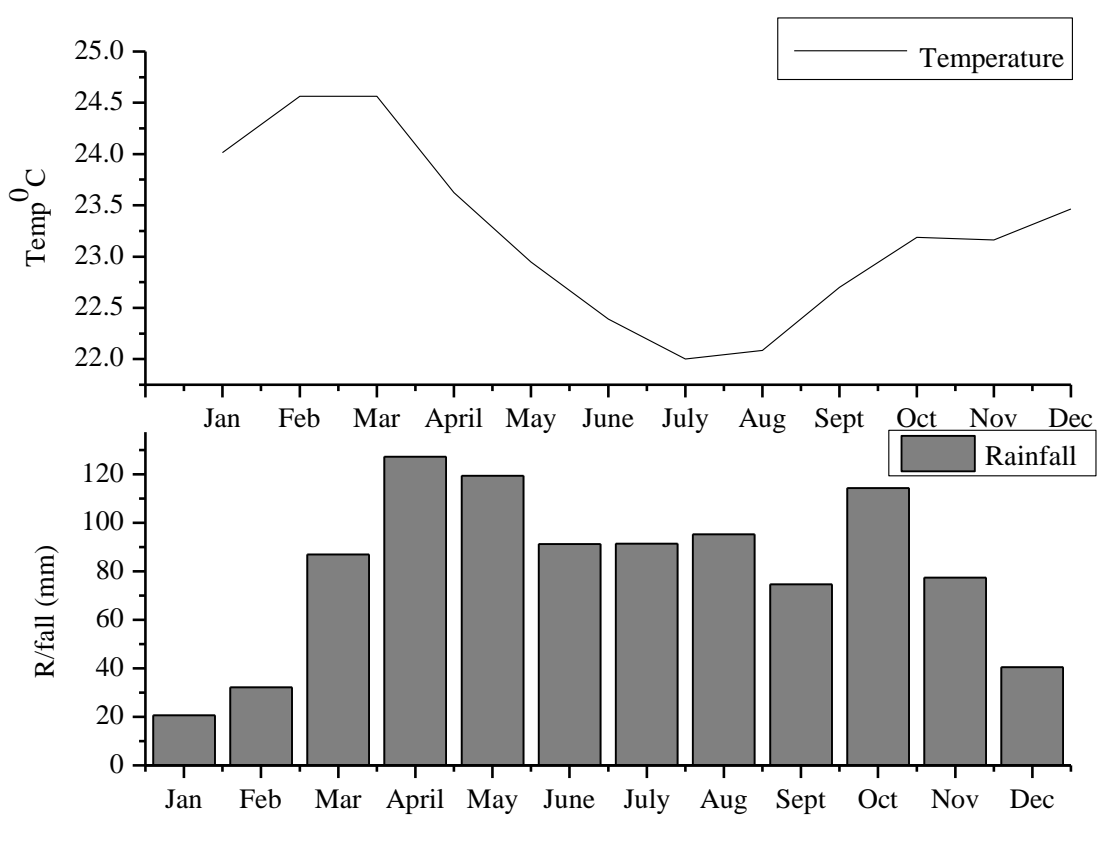

Figure 2. Mean Historical monthly temperature and rainfall computed by averaging area records of selected stations in Kwmz for the period 1900-2009.

Five main catchments under the Kyoga water management zone (Kwmz) contribute to the water base of Kyoga sub-basin (COWI 2010). These include:

a) Karamoja (Kapiri), which contributes to two seasonal rivers namely Okok and Okere, which join the lake by discharging into the wetland system around Lake.

b) Bisinia-Sironko which covers the river systems of Sironko, Sipi, Muyembe and Manafwa and those rivers that flow from the surrounding volcanic mountains of Elgon, Napak and Kadam;

c) Lake Kyoga sub-catchment has streams entering the lake from the south such as Sezibwa and Victoria Nile;

d) Mpologoma dominated by Mpologoma - Malaba river systems and lastly, 
e) Kwania which covers L. Kwania and the wetland systems found around Amolatar, Dokolo and Apac.

The catchments and the river systems shown in figure 1 flow into Lake Kyoga, whereas river Nile takes water out of the lake.

Direct precipitation over the major lake amounts to about 6 billion $\mathrm{m}^{3} / \mathrm{yr}$ while the mean annual outflow from the system is 27 billion $\mathrm{m}^{3}$ (COWI 2010). Ramsar documentation points out the following characteristics among others, that Lake Kyoga margins are fringed by cyperus papyrus, which often detaches to produce floating islands, due to changes in water levels. The swamps are dominated by papyrus, but seasonal flood plains are occupied with grasses and some trees in less deeply inundated areas. The lakes of Kyoga complex support important commercial fisheries in which Latesniloticus (Nile perch) constitutes $60-70 \%$ of the total annual catch. The lakes are however, fished only by artisans who also hunt crocodiles for their skins and are at the point of extinction.

\section{Data and Method}

\section{Data}

The land cover index was derived from the $30 \times 30 \mathrm{~m}$ resolution of Landsat images obtained from USGS sites (http://glovis.usgs.gov/) and (http://earthexplorer.usgs.gov/). In the analysis, Landsat imagery scenes (path 171, row 059) for January 1986, 1995, and 2010 covering Lake Kyoga sub-basin in Uganda were considered (see table 3, column 1). The decision to base our analysis on the month of January was to ensure that quality of the images is not compromised due to the effects of cloud cover. Thus, it was necessary to use scenes acquired during minimum rainfall events. Secondly, soil moisture could be minimal during this period and therefore any index calculated from the satellite images would not be affected by background noise (soil moisture). Further still to overcome the changes that may be brought about by radiance changes caused by other factors like the sun angle, satellite scenes acquired for the same season of the year were selected.

\section{Image pre-processing}

Pre-processing of the acquired Landsat images in this study necessitated converting optical band data to top of atmosphere reflectance values, as well as extracting the region of interest using ENVI 4.7 software and GIS. The MNDWI was selected as a spectral processing parameter to produce a greyscale image where water is bright.

\section{Method}

In the present study changes in areal water body computed by using the Modified Normalised Difference Water Index (MNDWI) based on TM and ETM+ spectral bands. The index was later applied to delineated images to enhance the water features. The MNDWI (see equation 1 in Table 1) is particularly suitable since it can enhance open water features while efficiently suppressing and even removing built-up land, vegetation and soil (Xu 2006). Further, the

middle infrared (MIR) spectral region i.e., TM band 5, is regarded as an effective 
discriminator of surface water bodies from other non-water or land surface features (Ji et al. 2009). The spatio-temporal changes in the lakes and rivers existing within the Lake Kyoga drainage sub-basin were analysed using GIS (ver 10.1) software. The images were reclassified into a "No water", "Low water", "Moderate water" and "High water" classes based on pixel values (Table 3) as thresholds. Pixel counts have been represented as percentages. Percentage change with in the different classes was calculated using 1986 as the base year.

In order to account for the observed changes in surface water bodies in Lake Kyoga sub-basin, the basin's climatic characteristics was analysed using the historical, monthly precipitation data. In particular, the SPI, described in McKee et al. (1995) was used to quantify the rainfall deficit at various time scales. In this study, the SPI was calculated for the different temporal scales e.g., December, January and February (DJF) of observed rainfall totals (Table 1, step 4). In the analysis, an averaging period of 3 months was used to account for lag and cumulative effects of precipitation (Shamsipour et al. 2011). The resulting SPI series was further categorized into the 30-year period also known as a 'normal' in accordance with World Meteorological Organization (WMO) requirement and then computed using equations put forward by (Awange et al. 2008). Applying Equation in step 7 (Table 1), one is able to obtain percentage precipitation of a "normal".

A DSI is determined by considering all observations which are less than $25 \%$ ( first quartile) of the ranked historical records to be dry, while those which are more than $75 \%$ ( third quartile) are considered wet. Awange et al (2008) illustrates severity classification scale as: Wet $(>75 \%) ; 25<$ Near normal < 75\%; Drought $<25 \%$. Drought season and year is identified when anomaly in rainfall is below the drought threshold line (i.e., DSI of $25 \%$ ). Table 1 depicts some of the equations used in the different steps and methods utilized in the present study.

\section{Result and discussion}

\section{Climatology}

Rainfall is the main source of water over the Lake Kyoga drainage sub-basin. An analysis of the climatic conditions over the sub-basin for the period 1940 - 2009 is given in this section. Table 2 shows the meteorological stations and associated observed time series that were used in the analysis including the associated rainfall characteristics. Values in italic denote station series, which were serially correlated at $95 \%$ (see column 7, table 2). Implying that, the vonneumann ratio of annual series of Tororo and Mukono meteorological stations show data that does not come from the same random process. During this period of analysis, Serere agricultural research station, found in the centre of the sub-basin recorded the highest total rainfall in 1996. Five of the nine stations recorded high rainfall in the 1960s. Kotido meteorological station in the far north of the zone has the highest rainfall variability of $28 \%$ followed by Kangole (25\%). Within this period of analysis Kangole received its highest total rainfall in 1961 and recorded its lowest total the following year (Table 2). 
Table 1. Summary of steps and methods used in the study.

\begin{tabular}{|c|c|c|c|}
\hline & Step & \begin{tabular}{|l} 
Process \\
\end{tabular} & Notes \\
\hline 1 & $\begin{array}{l}\text { Delineating surface water } \\
\text { in Landsat ETM+/TM } \\
\text { imagery. }\end{array}$ & $\begin{array}{l}M N D W I_{L_{2,5}}=\left(P_{L_{2}}-P_{L_{5}}\right) /\left(P_{L_{2}}+P_{L_{5}}\right) \\
(\mathrm{Xu} 2006 ; \text { ji et al 2009) }\end{array}$ & $\begin{array}{l}\text { where } P_{L 2} \text { and } P_{L 5} \text { are the reflectance's of } \\
\text { bands } 2 \text { and } 5 .\end{array}$ \\
\hline 2 & $\begin{array}{ll}\text { Rainfall } & \text { characteristics } \\
\text { analysis } & \end{array}$ & $\begin{array}{l}\text { Standard Deviation (SD), Coefficient of } \\
\text { Variation (CV) and Percentage } \\
\text { contribution to annual total rainfall. }\end{array}$ & $\begin{array}{l}\text { Computed for monthly and seasonal time } \\
\text { steps. }\end{array}$ \\
\hline 3 & $\begin{array}{l}\text { Monthly rainfall data, } \\
\text { obtained from UDM, } \\
\text { UBOS }(1940-2009)\end{array}$ & $\begin{array}{l}M_{s y}=\left(R_{s y}-\bar{R}_{s}\right) / \sigma_{s} \\
M_{r y}=\left(1 / N_{j}\right) \sum_{s=1}^{N_{s}} M_{s y} \\
v(\text { time })=\frac{\sum N_{j} M_{r y}{ }^{2}}{J-1} \\
v(\text { area })=\frac{n-\sum N_{j} M_{r y}{ }^{2}}{n-J}\end{array}$ & $\begin{array}{l}\text { Normalizing rainfall data series } \\
\text { where } N_{j} \text { is the number of regional stations } \\
\text { operating in the year } j \\
\text { It has to be shown that the geographical } \\
\text { variations of }\left(M_{s y}\right) \text { are small, compared } \\
\text { to the temporal variations (Kraus 1977, } \\
\text { Nicholson 1986, Türkeş 1996) }\end{array}$ \\
\hline 4 & $\begin{array}{l}\text { Quantifying rainfall deficit } \\
\text { for various time scales } \\
\text { (using SPI). }\end{array}$ & $\begin{array}{l}S P I=\frac{x-\bar{x}}{S}, \\
\text { (Agnew 2000, Livada and } \\
\text { Assimakopoulos 2007) }\end{array}$ & $\begin{array}{l}\text { Where } x \text { is the monthly meteorological } \\
\text { variable, } \bar{x} \text { is its } 3 \text {-month mean value, } \\
\text { with } s \text { as the standard deviation calculated } \\
\text { from the whole time series of monthly } \\
\text { values. }\end{array}$ \\
\hline 5 & $\begin{array}{l}\text { Drought Severity } \\
\text { Index(DSI): } \\
\text { Awange et al (2008), }\end{array}$ & $\bar{S}_{m}=\frac{1}{3} \sum_{m=1}^{3} M_{t}$ & $\begin{array}{l}\text { Seasonal means } \overline{S_{m}} \text { are obtained by } \\
\text { averaging the monthly totals } M_{t} \text { for three } \\
\text { months (3) of a particular season (for this } \\
\text { case DJF). }\end{array}$ \\
\hline 6 & & $A_{t}=\frac{1}{12} \sum_{m=1}^{12} M_{t}$ & $\begin{array}{l}\text { While for annual totals } A_{t} \text {, the summation } \\
\text { of twelve (12) monthly totals } M_{t} \text { was } \\
\text { taken for a given year. }\end{array}$ \\
\hline 7 & & $P_{n}=\left[\frac{A_{p}}{N}\right] \times 100$ & $\begin{array}{l}\text { Applying Eq. In step (5) and (6), the } \\
\text { normal precipitation } N \text { - a (30-year) mean is } \\
\text { obtained. Normal precipitation is then } \\
\text { used to compute the percentage of normal } \\
P_{n} \text { (quartile), where } \mathrm{A}_{\mathrm{p}} \text { is the actual } \\
\text { precipitation. }\end{array}$ \\
\hline
\end{tabular}


Table 2. Characteristics of annual rainfall data for Lake Kyoga Wmz between 1940- 2009.

\begin{tabular}{|l|l|l|l|l|l|l|l|l|}
\hline & $\begin{array}{l}\text { Mean } \\
\text { annual } \\
\text { R/fall } \\
(\mathbf{m m})\end{array}$ & $\begin{array}{l}\text { Highest } \\
\text { annual } \\
\text { total R/fall } \\
(\mathbf{m m})\end{array}$ & $\begin{array}{l}\text { Year } \\
\text { of } \\
\text { event }\end{array}$ & $\begin{array}{l}\text { Lowest } \\
\text { annual } \\
\text { total R/fall } \\
(\mathbf{m m})\end{array}$ & $\begin{array}{l}\text { Year } \\
\text { of } \\
\text { event }\end{array}$ & $\begin{array}{l}\text { Serial corr. } \\
\text { coeff. } \\
\mathbf{( 9 5 \% )}\end{array}$ & $\begin{array}{l}\text { Von- } \\
\text { at } \\
\text { neumann } \\
\text { Ratio at } \\
\mathbf{9 9 \%}\end{array}$ & $\begin{array}{l}\text { Coefficient } \\
\text { af } \\
\text { Variation } \\
\text { \% }\end{array}$ \\
\hline Tororo Met & 1462 & 1981 & 1961 & 879 & 1949 & 0.29 & 1.3 & 17 \\
\hline Mutai forest & 1359 & 2238 & 1961 & 943 & 1973 & 0.04 & 1.9 & 15 \\
\hline Mukono Agric. Sta. & 1355 & 2244 & 1960 & 772 & 1972 & 0.50 & 0.8 & 23 \\
\hline Kangole & 660 & 1089 & 1961 & 410 & 1962 & 0.02 & 2.0 & 25 \\
\hline Serere Agric. Sta. & 1376 & 2378 & 1996 & 939 & 1939 & 0.00 & 2.0 & 16 \\
\hline Soroti Met. Sta. & 1336 & 2032 & 1915 & 851 & 1957 & 0.10 & 1.7 & 19 \\
\hline Kibale VTC. Sta. & 1361 & 2047 & 1961 & 626 & 1980 & 0.06 & 1.9 & 18 \\
\hline Mbale & 1224 & 1789 & 1951 & 807 & 1927 & 0.16 & 1.7 & 19 \\
\hline Kotido & 677 & 1145 & 1946 & 351 & 1965 & 0.15 & 1.7 & 28 \\
\hline
\end{tabular}

Annual precipitation data recorded in Kyoga sub-basin from 1940 - 2009 show decades of average, below average and above average rainfall. Three long spans of below average rains are evident between 1940 and 1960, around the 1970s and 1980s in Kyoga sub-basin (see Fig. 3). Other particularly wet periods were experienced in early 1950s, 1960s, late 1970s and the 1990s. Lake Kyoga drainage sub-basin is wide with some mountainous topography at its edges, which can cause variation in climate, thereby producing spatial heterogeneities in temperature and precipitation. So a degree of disparity in SPI values between the stations should be expected.

Figure 4 shows that there is a remarkable consistency in the SPI for the month of January in most years. In particular it can be observed that, the sub-basin experienced drought conditions (negative SPI) in the month of January. In some years the sub-basin experienced relatively wetter conditions as a whole, with the SPI indicating positive rainfall anomalies. There are 24 years for instance out of the 70 year period of study when January experienced above average rainfall (Figure 4). 


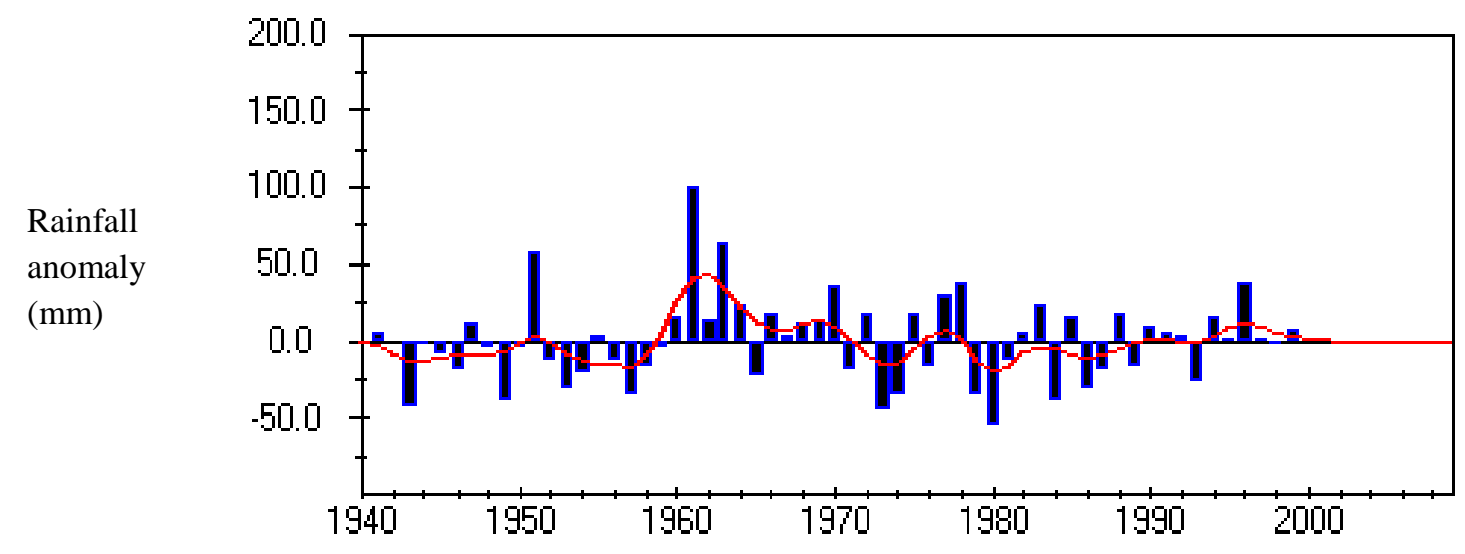

Figure 3. Total rainfall anomaly $(\mathrm{mm})$ for Lake Kyoga sub-basin during the period $1940-$ 2009. Variability at the end is constant because of data effect brought about by filling gaps as explained in (Nsubuga et al, 2014).

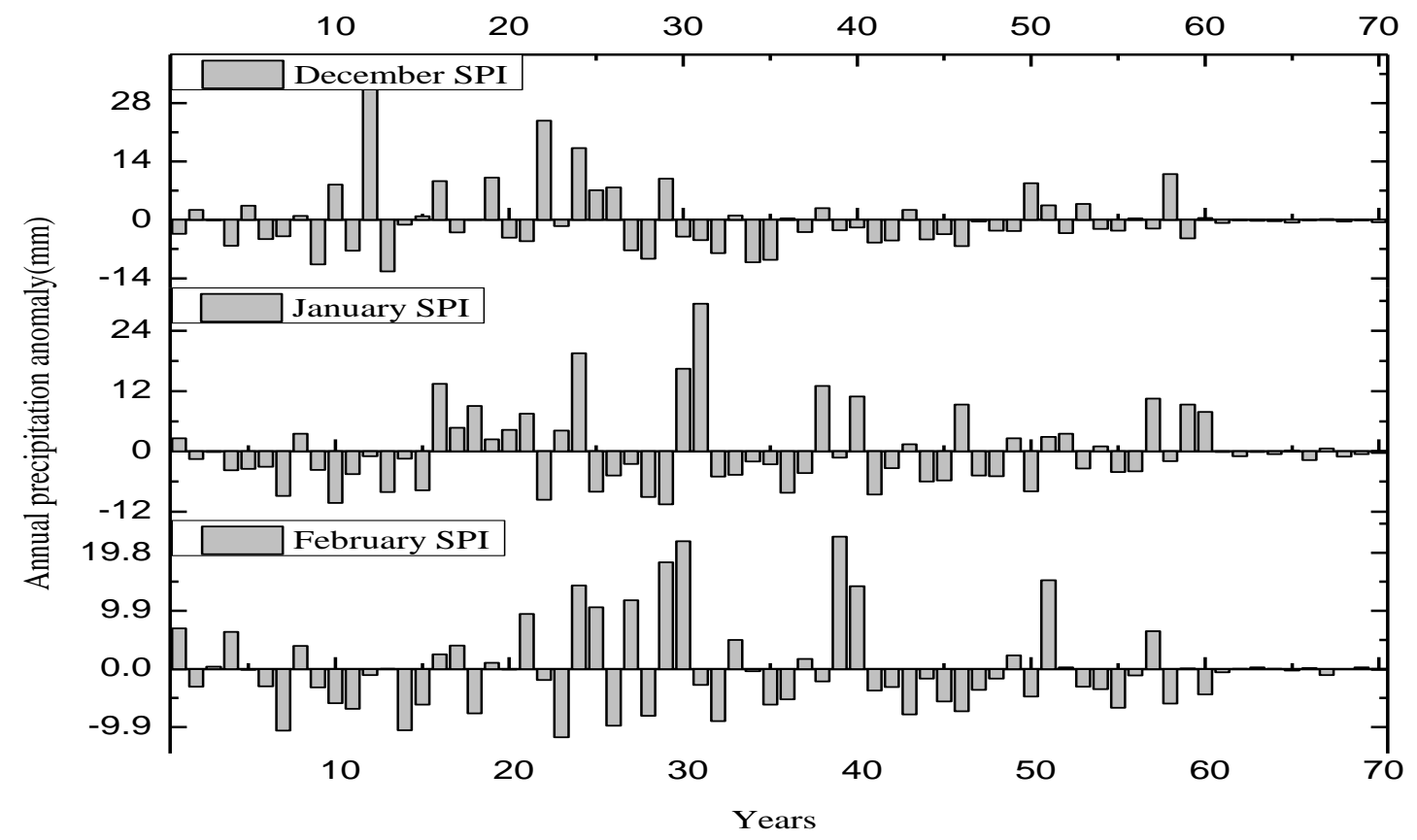

Figure 4. Standardized annual precipitation anomalies for the area average annual series of Kyoga drainage sub-basin using the DJF base period.

\section{Satellite derived changes}

The Green and MIR spectral bands of the TM/ETM+ were used in the MNDWI model to measure the extent of surface-water area and variation thereof in January over different years. Figure 5 illustrates the areal extent of surface-water over the Lake Kyoga basin. A definition of four classes namely; no water (dry land), low water (areas that experience seasonal 
flooding), moderate water (i.e permanently flooded) and high water (deep water) with corresponding thresholds using pixel values has been set as indicated in Table 3.

Differences in pixel counts between the years under consideration have been noted. The differences could be attributed to geometric errors.

Table 3. Percentage change of surface water area for the different classes in the Kyoga basin. Classes are defined by colour as indicated in figure 5 .

\begin{tabular}{|c|c|c|c|c|c|c|c|c|c|}
\hline Landsat/Image & \multicolumn{2}{|c|}{ Pixel Value 1 } & \multicolumn{2}{|c|}{ Pixel Value 2 } & \multicolumn{2}{c|}{ Pixel Value 3 } & \multicolumn{2}{c|}{ Pixel Value 4 } & \\
\hline $\begin{array}{l}\text { Year and date } \\
\text { of detection }\end{array}$ & $\begin{array}{c}\text { No } \\
\text { water }\end{array}$ & Count & $\begin{array}{c}\text { Low } \\
\text { water }\end{array}$ & Count & $\begin{array}{c}\text { Moderate } \\
\text { water }\end{array}$ & Count & $\begin{array}{c}\text { High } \\
\text { water }\end{array}$ & Count & $\begin{array}{c}\text { Total } \\
\text { count }\end{array}$ \\
\hline $1986-01-10$ & $50 \%$ & 18601207 & $41 \%$ & 15310997 & $2.4 \%$ & 891434 & $6.4 \%$ & 2379818 & 37183456 \\
\hline $1995-01-03$ & $49.7 \%$ & 184322994 & $41.6 \%$ & 15416638 & $2.6 \%$ & 963976 & $5.98 \%$ & 2217269 & 37030877 \\
\hline $2010-01-12$ & $46.5 \%$ & 17564904 & $43.8 \%$ & 16548844 & $0.8 \%$ & 313401 & 8.7 & 3288107 & 37715256 \\
\hline$\%$ Change & $7 \%$ & & $6.8 \%$ & & $65 \%$ & & $36 \%$ & & \\
\hline
\end{tabular}

Analysis reveals that, class of no water in the sub-basin has declined steadily by $7 \%$. Regions of low water have increased by more or less the same percentage of $6.8 \%$. The moderate water class was high in 1995 and declined by $65 \%$ by 2010. High water class shows an increase of 36\% in 1995, implying that areas that were not under water in 1986 (Figure 5) have been covered by water in 2010. Visual inspection of the images for 1986 shows a detaching Lake Kyoga from the Kwania lake water system, which is evidence of low water in the basin. While classifying a Landsat image for 2001 from Paliisa district, Otukei and Blaschke (2010) realised that the class of open water was absent. The low water level was also observed within the Nile basin when lake Nasser receded to 158m in 1987 (Abdelsalam et al. 2008).

By 2010, water had occupied the areas that seemed detached as seen in figure 5. The increase in surface-water area can be attributed to the reduction in the wetland size in the two basins (Kyoga and Victoria). Paliisa district also found in Kwmz, herbaceous wetlands had decreased by 2001 as found out in a separate study by (Otukei and Blaschke 2010). Wetlands have large storage capacity for water. According to NEMA (2008), reduction in the wetlands around the study area was $26.5 \%$ by 2008 . Other water resource developments like the construction of Nalubaale power dam along the Victoria Nile created another water outlet from Lake Victoria into the basin, which may have led to the increase in surface-water area in the receiving basin. There are also records of frequent floods around the basin recently, which is evidence that the basin is undergoing hydrological changes. It is thus important for water managers to monitor water surface area changes in this era of climate change before carrying out upstream developments. This is possible through remotely sensed imagery.

The available observational records and historical information show that variations in the level of east African lakes are closely related to previous trends in rainfall patterns (see e.g Anyah and Semazzi 2004). The DSI values, presented in Table 4 illustrate the drought years in both Kyoga and Victoria drainage sub-basins in Uganda. Because Lake Victoria basin is 
part of the Kyoga catchment, a change in the water regime in the Victoria basin is reflected in the amount of water received in Kyoga basin. There is a relationship between the drought years in the two sub-basins in the first normal (30 years) than in the second normal during the period of analysis (See years denoted in italics, Table 4).

Table 4 Drought years compared for L. Kyoga and Victoria drainage sub-basins in Uganda. Similarities in the sub-basins have been shown in italics and underlined.

\begin{tabular}{|l|l|l|l|}
\hline $\begin{array}{l}\text { Series } \\
\text { variables }\end{array}$ & $\begin{array}{l}\text { Climatic } \\
\text { Normal }\end{array}$ & Lake Kyoga & Lake Victoria \\
\hline Annual & $1940-1969$ & $\underline{1943}, 1949, \underline{1953}, 1957,1958, \underline{1965}$ & $\underline{1943}, 1946,1952, \underline{1953}, 1959, \underline{1965}$ \\
\cline { 2 - 5 } & $1970-1999$ & $1973,1974,1979, \underline{1980}, 1984,1986,1993$ & $1970,1971, \underline{1980,1982,1983,1985}$ \\
\hline
\end{tabular}

In particular, the 1986 drought event is captured well by the surface-water area change analysis, indicated by the $50 \%$ and $41 \%$ of no and low water coverage respectively, while the area under high water was 6.4\%. Awange et al (2008) also identified 8 drought seasons within the Lake Victoria basin period between 1990 and 1999. But because of some differences in data and spatial coverage of the two studies, our results on droughts slightly differ with those reported in Awange et al (2008). Another prominent drought period was the 2004/5, when the water level in Lake Victoria dropped by a meter below the 10 year average (Kull 2006).

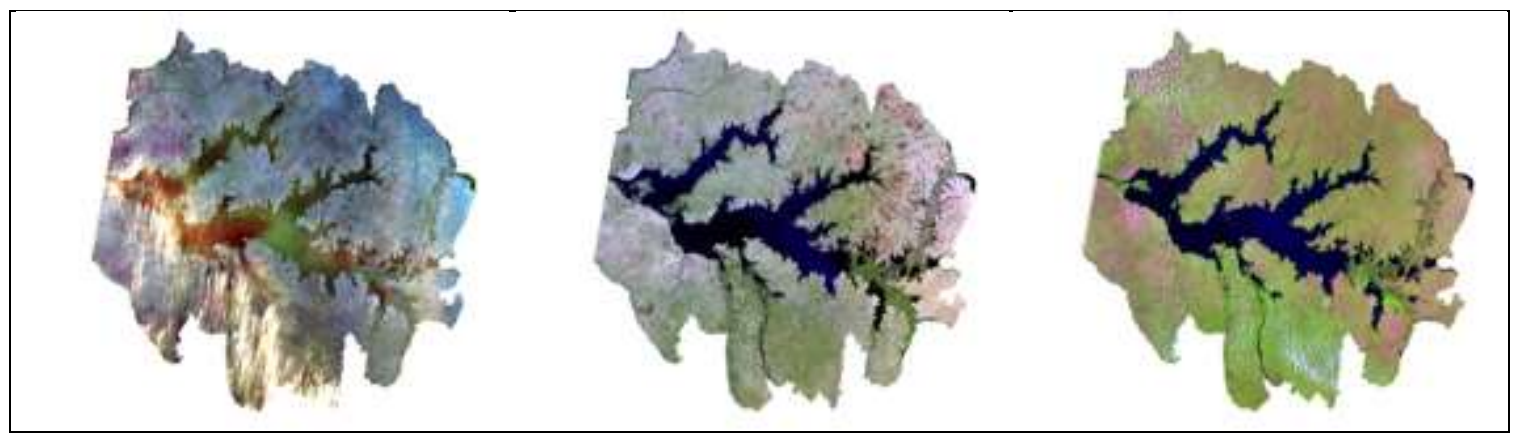

5(a) Lake Kyoga sub-basin delineated from Landsat composite images for January 1986, 1995 and 2010 (left to right) using band combination 7, 4 and 2.
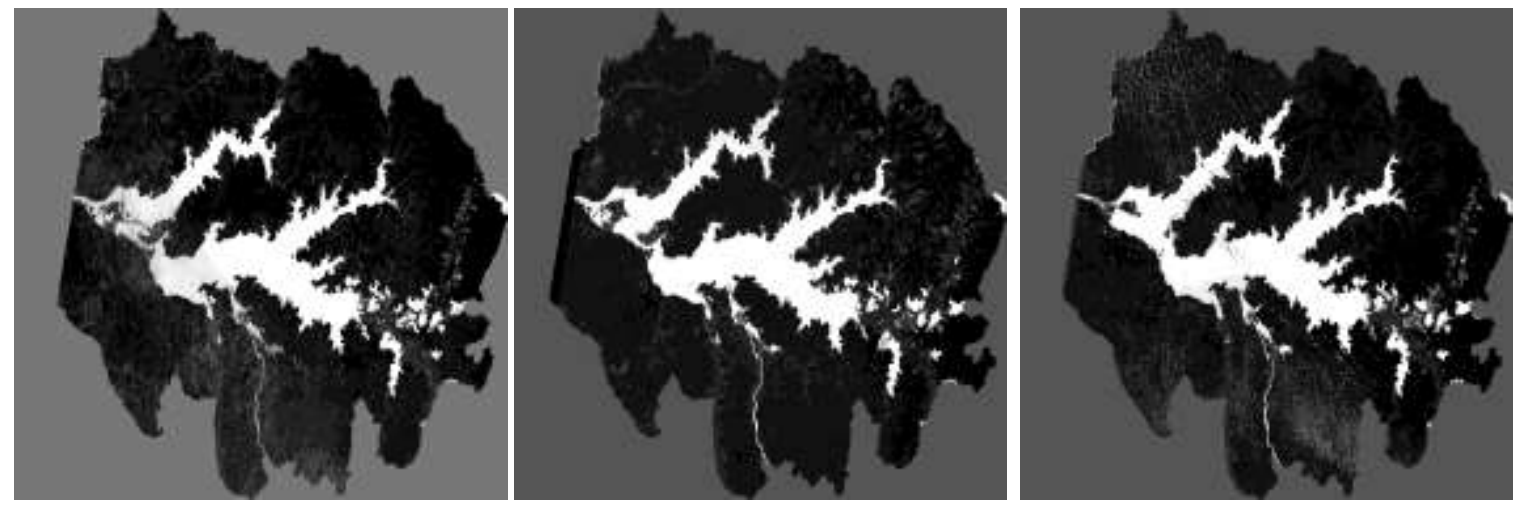

5(b) Enhanced images of Lake Kyoga sub-basin after applying the MDWI for 1986, 1995 and 2010 images (left to right) 


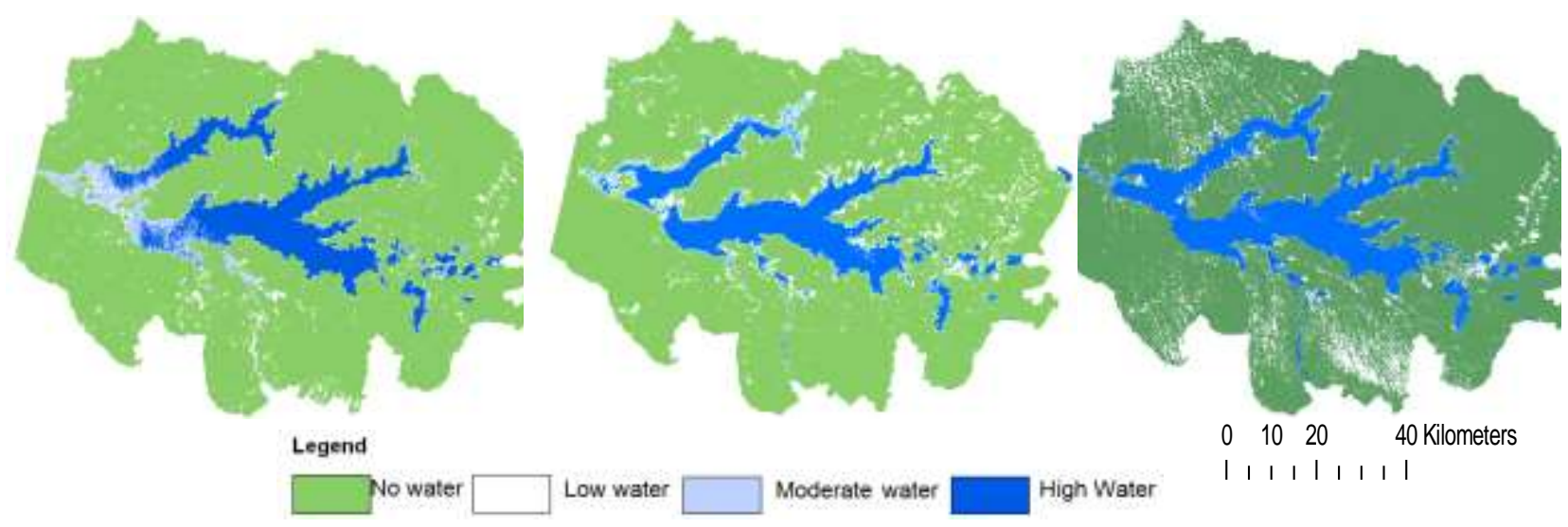

5(c) Reclassified images of Lake Kyoga sub-basin for January 1986, 1995 and 2010 (left to right).

Figure 5 showing satellite output images prior to $(a, b)$ and after calculating (c) change in surface water area of Lake Kyoga sub-basin.

\section{Variability}

Changes in precipitation and temperature are often reflected in changes in water resources and therefore impacts on all sectors that depend directly or indirectly on the water resources (Estrela et al. 2012). Furthermore, variations in these vital climatic variables across the selected basin in Uganda are often a proxy for climate variability in Uganda. Climate change and variability in Uganda pose very serious national challenges and risks across various sectors such as agriculture, water resources and energy, which support the economy and the wellbeing of its people. Conducting impact assessment studies, which is not easy because of natural hydrological variability, can ameliorate these challenges and risks and effects of water abstractions on flow discharges.

Lake Kyoga receives water from Lake Victoria through the Victoria Nile (Fig.1). In the past years, the Lake Kyoga water levels have shown a significant downward trend with the current level being around the long term average level. Between years 2000 and 2010, the average water was 10334 amsl (DWRM 2011). According to DWRM (2011) the current lake elevation is still in the natural range of the lake but what is worrying, is the rate at which the levels are receding (See Fig. 6). 


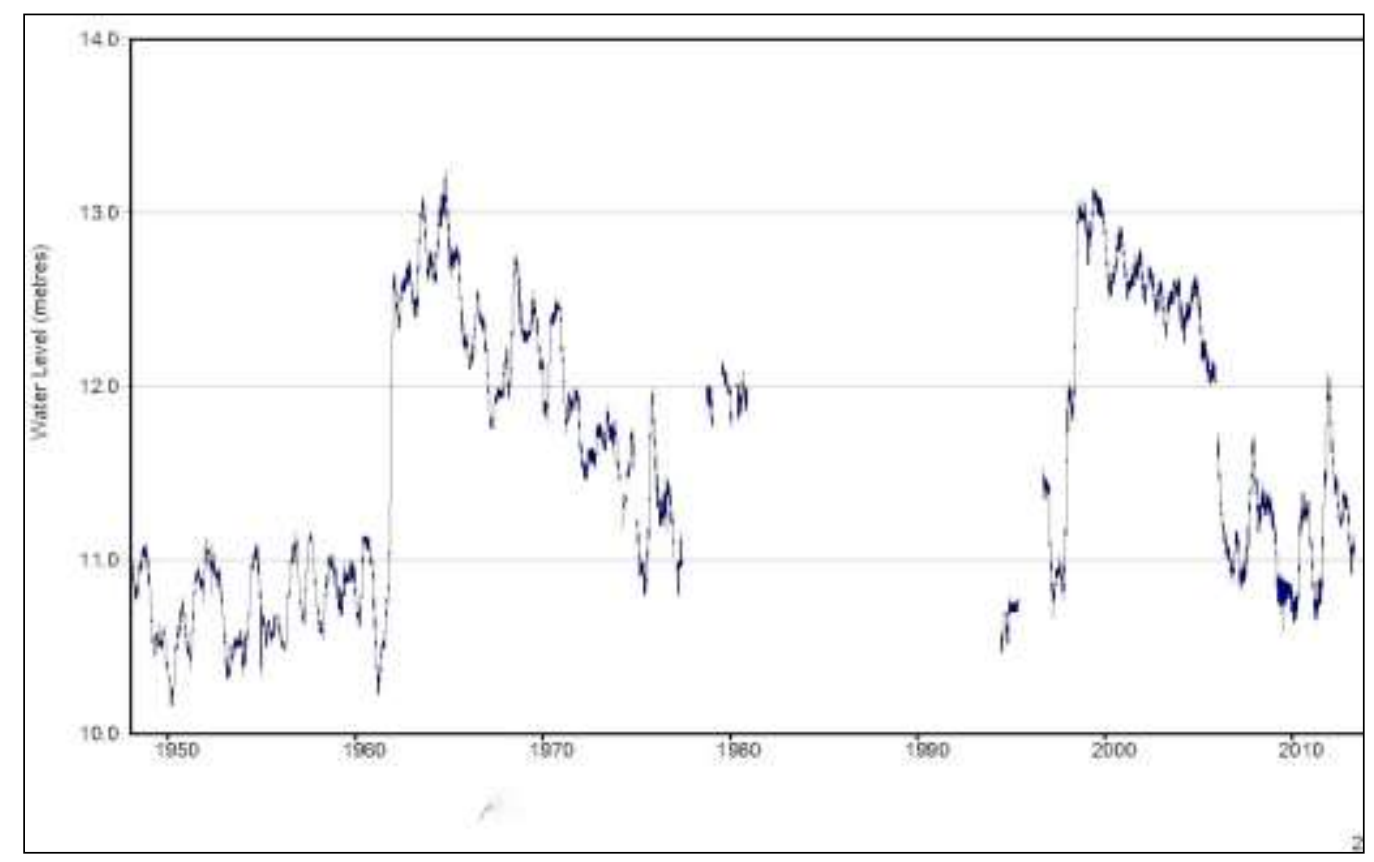

Figure 6 showing annual water level (metres) of Lake Kyoga (1950- 2013) measured at Bugondo pier (Source of data DWRM, Entebbe)

Historical levels of Lake Kyoga varied between a minimum of $10.2 \mathrm{~m}$ and a maximum of 13.2 on the Bugondo pier gauge. The figure shows that significant levels of variations can occur over a short period of time. Between 1961 and 1964, water level in Lake Kyoga rose rapidly by $2.5 \mathrm{~m}$ as a consequence of extraordinary high rainfall experienced within the catchment area. Since that time the levels have remained high, but appear to be declining.

This variability is evident in the surface-water area changes detected by the use of remotely sensed imagery as shown in (Figure 5) above. For instance the El-Nino rains of 1995- 1997, raised level of water in Lake Kyoga (Figure 6). This was also detected along the Nile valley system when Lake Nasser in Egypt overflowed through the Tushka valley and subsequently flooded the Tushka depression that led to formation of lakes that have since diminished (Abdelsalam et al. 2008). This increase in water level is not reflected in the Lake Kyoga January images, because rains started in November of 1995. In table 3, Landsat image for 1995 shows a low total pixel count. It is after the end year, that January means rains also rise (Fig.7) and start declining after the year 2000. Further observation is made during the early years of $19^{\text {th }}$ century when the region experienced prolonged drought $(\mathrm{Ba}$ and Nicholson 1998) there was a significant fall in lake levels (see also Figure 7 with table 4) until the 1960s when rainfall totals shot up. 


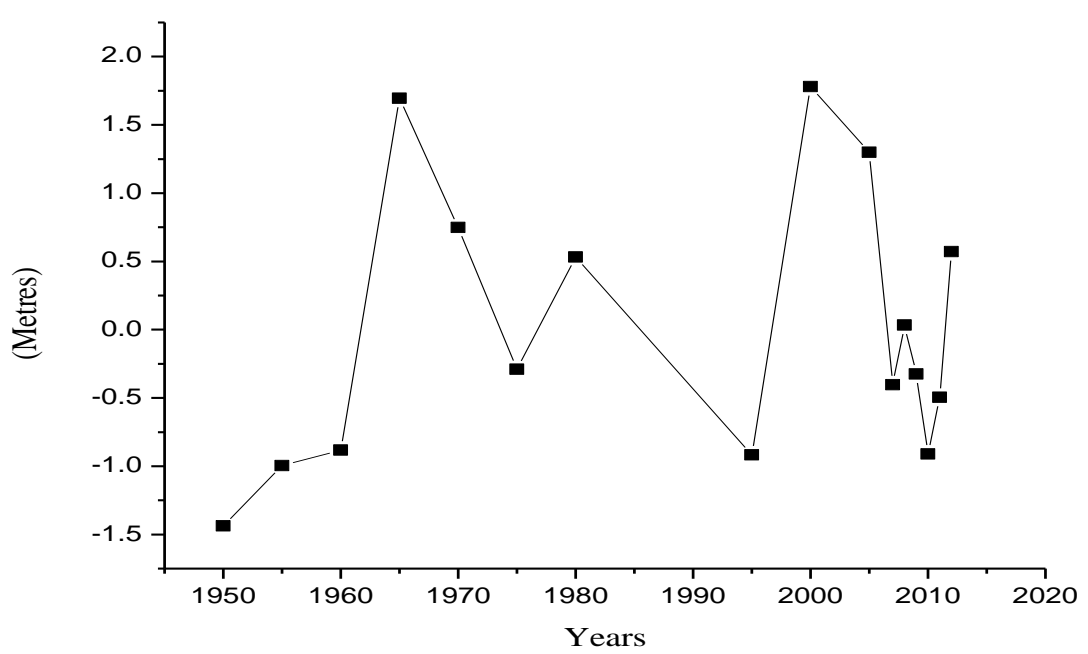

Figure 7 January mean lake levels for Lake Kyoga taken at Bugondo pier (1950- 2012). Data source: DWRM, Entebbe.

\section{Livelihoods and vulnerability}

Droughts significantly affect a country's water resources, hydropower production and other related industry like agriculture. For example, the 1980s according to Hulme (1992) were drought years that had consequences on food security for the African continent. When the above normal rainfall was received over the east African region during the 1960s, Lake Victoria level rose to about $2 \mathrm{~m}$, with most of the basin experiencing heavy flooding (Anyamba 1983). Also there is evidence of increase in water levels of Lake Kyoga for the same period (Figure 7), hence a relationship between climate variability and change in water level. Such variability has consequences on human activity, migration trends and the economy in general that requires investigation.

For example, north-eastern Uganda where Kotido and Kangole weather stations are located is a dry area, inhabited mainly by the Karimojong whose main activity is pastoralism. The high variability of rainfall compels pastoralists to migrate and search for grass and water. The movement of Karimojong causes a lot of friction with the neighbouring communities like the Ateso and Pokot and often results in cattle rustling and insecurity in Kenya and Uganda. Currently the Kwmz has a population of more than nine million who are vulnerable because they depend largely on an agriculture and trade. Variability in rainfall that influences water levels can greatly affect their form of livelihoods and water related natural resources occupations. It is important therefore in future to understand the level of water stress, its rate of change in order to determine the ability of the communities' resident here to adapt to changing conditions.

As a result of variations in the rainfall, these lakes in Kyoga basin require exceptional water management practices that would ensure that changes in climate do not cause a major effect on water availability and water stress, hence causing insecurity that may lead to the displacement of communities. Increasing water availability on the other hand may have a positive influence, which reduces water stress, but it can also have consequences of high and damaging runoff events. 


\section{Conclusions}

The detection of water body change effects is not simple because natural variability of the water cycle and the effects of water abstractions on flow discharges complicate the task of establishing clear trends. Studies focused on the use of Landsat imagery to detect changes in surface-water area have been extensively reported in numerous published works in recent years. However, majority of these studies tend to focus on exploring regional climate models, apply them on to scenarios of observed climate data to explain the effects of hydrological uncertainties on catchments. In the present work, Landsat satellite scenes over Lake Kyoga sub-basin (1986, 1995 and 2010) have been analyzed in order to investigate the spatialtemporal variability of areal surface-water masses.

Further, the derived areal surface-water changes have been compared with rainfall. Results illustrate that there is a linkage between surface water changes and climatic parameters. Additionally, the DSI and SPI parameters reveal a close relationship between the changes observed from images and the results from the two indices. The detected changes can be attributed to drainage systems characteristics and its management. Unmanaged systems are likely to be the most vulnerable to climate changes. During basin management plans, measures should take into account the different effects of climate in different water management sub-basins in Uganda. If the intense use of water resources continues, the environmental needs increase and the margin to increase available water resources is reduced, then it is most likely that current water uses will not be maintained in the future. The remote sensing technique and the MNDWI parameter can be used in WRM and also serve as an early warning mechanism. In conclusion, it becomes essential to improve assessments of the effects and to adapt water management plans to the already identified impacts and to the anticipated ones by using future scenarios.

Acknowledgements: USGS sites GLOVIS (http://glovis.usgs.gov/) and EarthExplorer (http://earthexplorer.usgs.gov/). EARS group for their constructive criticisms. And the DWRM, Entebbe for providing Lake level data.

\section{Reference}

Abdelsalam MG, Youssef AM, Arafat SM, Alfarhan (2008) Rise and demise of the new Lakes of Sahara, Geosphere, 4(2): 375-386.

Agnew CT (2000) "Using the SPI to identify drought", Drought Network News 12 (1): 6 -12.

Alcamo J, Flörke M \& Märker M (2007) "Future long-term changes in global water resources driven by socio-economic and climatic changes", Hydrological sciences journal, 52(2): 247 275. 
Anyah RO \& Semazzi FHM (2004) "Simulation of the sensitivity of Lake Victoria basin climate to lake surface temperatures", Theoretical and Applied Climatology 79: 55 -69.

Anyamba EK (1983) "On the monthly mean lower tropospheric circulations during the 1961/62 floods in East Africa”, Msc. Thesis, University of Nairobi.

Arshad M, Gomez R, Falconer A, Roper W, Summers M (2014) A remote sensing technique detecting and identifying water activity sites along irrigation canals. American Journal of Environmental Engineering and Science,1(1) 19-35.

Awange JL, Ogalo L, Bae K-H, Were P, Omondi P, Omute P \& Omullo M (2008) Falling Lake Victoria water levels: Is climate a contributing factor? Climate change 89: 281-297.

Ba MB \& Nicholson, SE (1998) "Analysis of convective activity and its relation to rainfall over the Rift valley Lakes of East Africa during 1983 - 1990 using the Meteosat Infrared channel", Journal of applied Meteorology 37:1250 -1264.

COWI (2010) "Operationalisation of catchment-based water resources management. Ministry of water and environment, Directorate of water resources management", September 2010, Kampala Uganda.

DWRM (2011) "The declining trends of water resources in Uganda: A case study of river Rwizi, Lake Wamala, Lake Victoria catchments and representative groundwater monitoring stations", Water Resources Monitoring and Assessment Division. Entebbe, Uganda.

Estrela T, Perez-Martin MA \& Vargas E (2012) "Impacts of climate change on water resources in Spain" Hydrological sciences journal 57(6): 1154- 1167.

Hulme, M (1992) "Rainfall changes in Africa: 1931- 1960 to 1961-1990", International Journal of Climatology 12: 685-699.

Ji L, Zhang L \& Wylie B (2009) "Analysis of dynamic thresholds for the normalized difference water index", Photogrammetric engineering and remote sensing 75 (11): 1307 1317.

Kraus EB (1977) "Subtropical Droughts and cross-Equatorial Energy transports", Monthly weather review. 105: 1009-1018.

Kull D (2006) Connections between recent water level drops in Lake Victoria, Dam operations and drought, viewed 24/03/2013, http://www.irn.org/programs/nile/pdf/060208vic.pdf.

Livada I \& Assimakopoulos VD (2007) "Spatial and temporal analysis of drought in Greece using the standardized precipitation index (SPI)", Theor. Appl. Climatol 89:143-153.

Lu D, Mausel P, Brondízio E \& Moran E (2004) "Change detection techniques", International Journal of Remote sensing 25 (12): 2365 - 2407. 
McFeeters SK (1996) "The use of the Normalized Difference Water Index (NDWI) in the delineation of open water features", International Journal of Remote Sensing, 17(7): 14251432.

McKee TB, Doesken NJ \& Kleist J (1995) "Drought monitoring with multiple time scales. Proceedings of the Ninth Conference on Applied Climatology", American Meteorological Society, $233-236$.

Mouchot MC, Alföldi T, De Lisle D \& McCullough G (1991) "Monitoring water bodies of the Mackenzie Delta by remote sensing methods", Arctic, 44 (1): 21 -28.

Nath RK \& Deb SK (2010) "Water-body area extraction from high resolution satellite images-An introduction, review and comparison", International Journal of Image Processing 3 (6): 353-372.

NEMA (2002) "State of Environment Report for Uganda (2002)" National Environment Management Authority (NEMA), Kampala.

NEMA (2008) "State of Environment Report for Uganda (2008)" National Environment Management Authority (NEMA), Kampala.

Nicholson SE (1986) "The nature of rainfall variability in Africa south of the equator", International Journal of Climatology 6: 515-530.

Niya AK, Alesheikh AA, Soltanpor M, Kheirkhahzarkesh (2013) Shoreline change mapping using remote sensing and GIS. International journal of remote sensing applications,3(3), 102-107.

Nsubuga FWN, Botai OJ, Olwoch JM, Rautenbach CJ.deW, Bevis Y, Adetunji AO. (2014). The nature of rainfall in the main drainage sub-basins of Uganda. Hydrological Sciences Journal, 59 (2), 278-299.

Ouma YO \& Tateishi R (2006) “A water index for rapid mapping of shoreline changes of five East African Rift Valley lakes: an empirical analysis using Landsat TM and ETM+ data”, International Journal of Remote Sensing 27 (15): 3153- 3181.

Rasuly A., Naghdifar R., Rasoli M (2010) Detecting of Arasban Forest changes applying image processing procedures and GIS techniques. Procedia environmental sciences, 2, $454-$ 464.

Schäfer ML \& Lundström JO (2012) "Detection of temporary flooded areas with potential floodwater mosquito production using imaging radar", International Journal of Remote sensing 33 (6): 1943 -1953.

Schultz GA (1997) Use of remote sensing data in a GIS environment for water resources management. Remote Sensing and Geographic Information Systems for Design and Operation of Water Resources Systems (Proceedings of Rabat Symposium S3, April, 1997). IAHS Publ.no 242, 1997. 
Shamsipour AA, Zawar-Reza P, Panah SKA \& Azizi G (2011) "Analysis of drought events for the semi- arid central plains of Iran with satellite and meteorological based indicators", International Journal of Remote Sensing 32 (24): 9559 - 9569.

Singh A (1989) "Digital change detection techniques using remotely- sensed data." International Journal of Remote sensing 10 (6): 989 -1003.

Song C, Huang B, Ke L (2013) Modeling and analysis of lake water storage changes on the Tibetan plateau using multi-mission satellite data. Remote sensing of the Environment, 135, 25-35.

Terekhin EA (2013) The procedure of seeking effective spectral indices for automated interpretation of water bodies (a case study of Belgorod Oblast). Geography and natural resources, 34 (3), 272-277.

Troitskaya YI, Rubushkina GV, Soustova IA, Balandina GN, Lebedev SA, Kostyanoi AG, Panyutin AA, Filina LV (2012) Satellite altimetry of inland water bodies. Water resources, 39(2), 184-199.

Otukei JR, Blaschke T (2010) Land cover change assessment using decision trees, support vector machines and maximum likelihood classification algorithms. International Journal of Applied Earth Observation and Geoinformation. 12s, s27-s31.

Türkeş M (1996) "Spatial and temporal analysis of annual rainfall variation in Turkey", International Journal of Climatology 16:1057- 1076.

UNWDR (2005) “Uganda National Water Development Report 2005”, Ministry of water and Environment. Kampala, Uganda.

Xu H (2006) "Modification of normalized difference water index (NDWI) to enhance open water features in remotely sensed imagery", International Journal of Remote Sensing 27(14): $3025-3033$.

Xu M, Cao C, Zhang H, Xue Y, Li Y, Guo J-P, Chang C, He Q, Gao M \& Li X (2009) "Change detection of the Tangjiashan barrier lake based on multi-source remote sensing data", IEEE Geoscience and remote sensing society, 303- 306. 